COALITION

POLITICS

A Multi-disciplinary

Study of Coalitions and their Implications for Governance

Editors

Hoolo 'Nyane

Motlamelle A Kapa
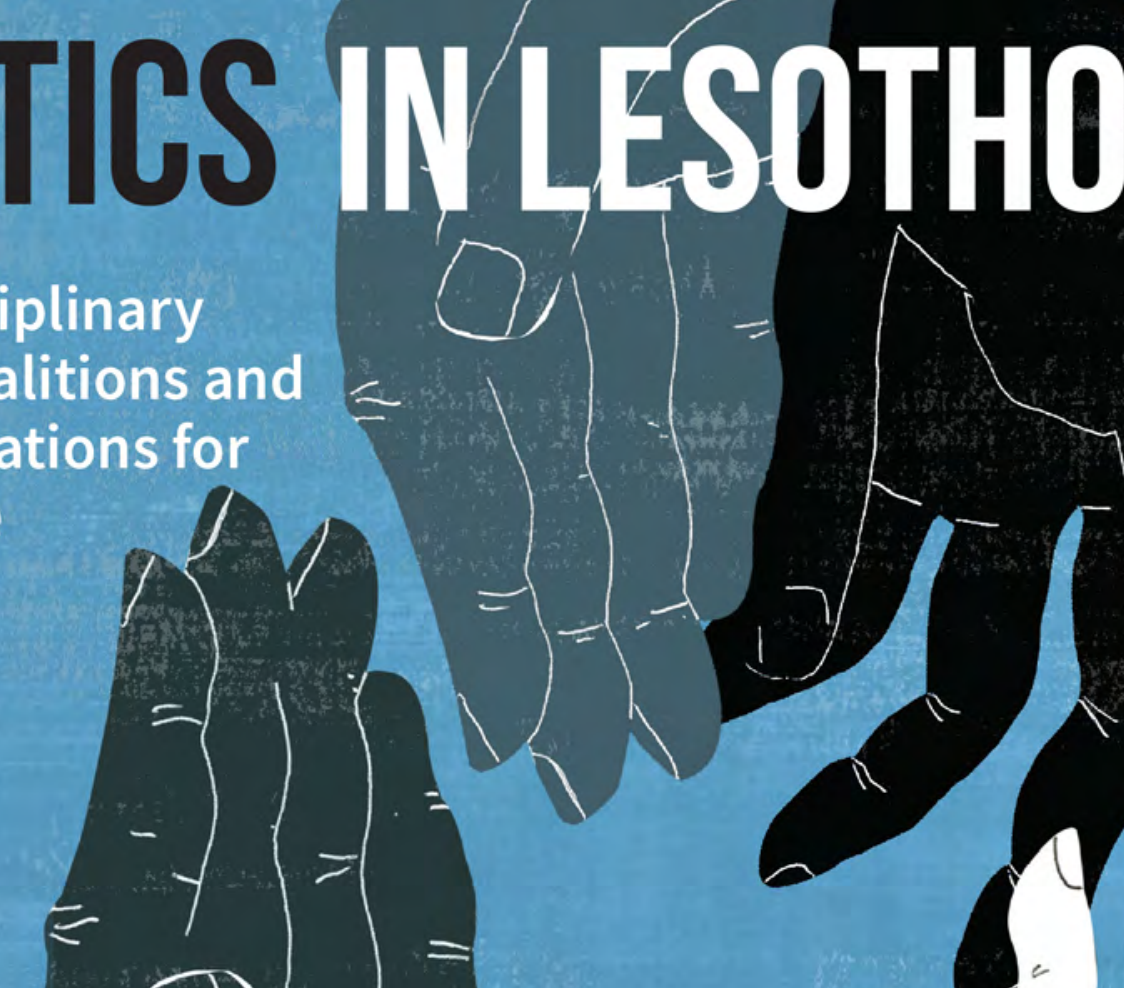

$\triangle$
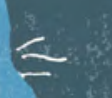


\title{
LIST OF ACRONYMS
}

\author{
$\mathrm{ABC}$ \\ All Basotho Convention \\ ACP \\ Alliance of Congress Parties \\ AD \\ Alliance of Democrats \\ AG \\ Attorney General \\ AJA \\ Administration of the Judiciary Act \\ AMHC \\ All Mauritian Hindu Congress \\ ANC \\ African National Congress \\ BAC \\ Basutoland African Congress \\ BAP \\ Basotho Action Party \\ BBDP \\ Basotho Batho Democratic Party \\ BCP \\ Basutoland Congress Party \\ BDNP \\ Basotho Democratic National Party \\ BNP \\ Basotho National Party \\ CAM \\ The Comité d'Action Musulman \\ CEDAW \\ Convention on the Elimination of All Forms of Discrimination Against \\ Women \\ CID \\ Criminal Investigation Division \\ CMW \\ Convention on the Protection of the Rights of all Migrant Workers and \\ Members of their Families \\ CORD Coalition for Reforms and Democracy \\ COVID-19 Coronavirus Disease of 2019 \\ CRPD Convention on the Rights of Persons with Disabilities \\ CSOs Civil Society Organisations \\ DC \\ Democratic Congress \\ DCEO \\ Directorate on Corruption and Economic Offences \\ DPL \\ Democratic Party of Lesotho \\ DPP \\ Director of Public Prosecutions \\ ECF \\ Extended Credit Facility
}




\begin{tabular}{|c|c|}
\hline ECK & Electoral Commission of Kenya \\
\hline EMB & Election Management Body \\
\hline FIU & Financial Intelligence Unit \\
\hline FORD & Forum for Restoration of Democracy \\
\hline FPTP & First-Past-The-Post \\
\hline GDP & Gross Domestic Product \\
\hline GNU & Government of National Unity \\
\hline HRC & Human Rights Committee/Council \\
\hline ICC & International Criminal Court \\
\hline ICCPR & International Covenant on Civil and Political Rights \\
\hline ICJ & International Commission of Jurists \\
\hline IFP & Inkatha Freedom Party \\
\hline IMF & International Monetary Fund \\
\hline IPA & Interim Political Authority \\
\hline JIMC & Monitoring and Implementation Committee \\
\hline JSC & Judicial Service Commission \\
\hline KANU & Kenya African National Union \\
\hline KSC & Kenya Social Congress \\
\hline LCD & Lesotho Congress for Democracy \\
\hline $\mathrm{LCN}$ & Lesotho Council of Non-Governmental Organisations \\
\hline LCS & Lesotho Correctional Services \\
\hline LDF & Lesotho Defence Force \\
\hline LHWC & Lesotho Highlands Water Commission \\
\hline LLA & Lesotho Liberation Army \\
\hline LMPS & Lesotho Mouted Police Service \\
\hline LP & Labour Party \\
\hline LPC & Lesotho People's Congress \\
\hline LPF & Lesotho Para-Military Force \\
\hline LWP & Lesotho Workers Party \\
\hline MCA & Millennium Challenge Account \\
\hline
\end{tabular}




\begin{tabular}{|c|c|}
\hline MEC & Movement for Economic Change \\
\hline MFP & Marematlou Freedom Party \\
\hline MMM & Mouvement Militant Mauricien \\
\hline MMP & Mixed Member Proportional \\
\hline MPs & Members of Parliament \\
\hline MSM & Mkenya Solidarity Movement \\
\hline NARC & National Rainbow Coalition \\
\hline NASA & National Super Alliance \\
\hline NDPC & National Dialogue Planning Committee \\
\hline NEC & National Executive Committee \\
\hline NIP & National Independence Party \\
\hline NLF & National Leaders' Forum \\
\hline NRA & National Reforms Authority \\
\hline NSS & National Security Services \\
\hline NUL & National University of Lesotho \\
\hline NYS & National Youth Service \\
\hline ODM & Orange Democratic Movement \\
\hline PAC & Public Accounts Committee \\
\hline PDP & Peoples Democratic Party \\
\hline PEFA & Public Expenditure and Financial Accountability \\
\hline PFD & Popular Front for Democracy \\
\hline PM & Prime Minister \\
\hline PMSD & Parti Mauricien Socialiste Democrate \\
\hline PMU & Police Mobile Unit \\
\hline PNU & Party of National Unity \\
\hline PR & Proportional Representation \\
\hline PSIC & Public Sector Investment Committee \\
\hline PSIP & Public Sector Investment Programme \\
\hline RCL & Reformed Congress of Lesotho \\
\hline RLDF & Royal Lesotho Defence Force \\
\hline
\end{tabular}




$\begin{array}{ll}\text { SACU } & \text { Southern African Customs Union } \\ \text { SADC } & \text { Southern Africa Development Community } \\ \text { SGR } & \text { Standard Gauge Railway } \\ \text { SMM } & \text { Single Member Majoritarian } \\ \text { SMMEs } & \text { Small, Micro and Medium Enterprises } \\ \text { SMP } & \text { Single Member Plurality } \\ \text { SOMILES } & \text { SADC Observer Mission to the Kingdom of Lesotho } \\ \text { SOU } & \text { Special Operations Unit } \\ \text { TNA } & \text { The National Alliance } \\ \text { TRC } & \text { Transformation Resource Centre } \\ \text { TRC } & \text { Truth and Reconciliation Commission } \\ \text { UDF } & \text { United Democratic Forum Party } \\ \text { UPR } & \text { Universal Periodic Review } \\ \text { URP } & \text { United Republican Party } \\ \text { WDM } & \text { Wiper Democratic Movement }\end{array}$




\section{THE ECONOMIC COST OF CONFLICT WITHIN COALITION GOVERMENTS IN LESOTHO FROM 2012 TO 2020}
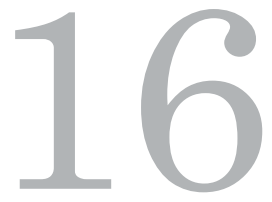

\section{Selibe Mochoboroane and Keneuoe Mots'oene}

\section{Introduction}

Lesotho has the coalition model of governance, characterised by a perpetual in-fighting between coalition partners since the beginning of the coalition governments in the country in 2012 with economic costs. The introduction of the mixed electoral system, with a strong proportionality element, brought about a paradigm shift from the dominant party system to inclusive politics and brought about a new phenomenon of a coalition government ('Nyane, 2017). Therefore, it was expected that, with the transition from a one-party government to a dispensation of coalitions since 2012, Lesotho would prosper through the realisation of economic development. However, political instability has kept the country's economic development sluggish. Within the last five and a half years, from January 2015 to June 2020, the country has held two snap elections due to political instability. Needless to add, the cost of maintaining coalition governments in Lesotho since the first coalition in 2012 to 2020 is massive compaired with the lesser economic development of the country.

Nowhere in history has Lesotho experienced so much loss of public revenue than it has during the coalition government, with remarkable negative effects on the country's socioeconomic development in the period from 2012 to 2020. The ensuing conflict that arises within and between the parties that form the coalition seems to be the main cause of the mortality of these coalitions, exposing the country to unavoidable costs which are directed to the individual citizens of Lesotho during and at the end of the coalition. The interand intra-party conflicts have not given the country a chance to realise its development 
potential, given that some of its resources are siphoned continuously for self-enrichment by individuals in their serving capacity as government officials. The economy is seriously constrained to generate the growth needed to adequately serve the needs of the nation, mainly the basic needs of the poor masses.

In exposing the economic cost of political conflict on the development of the country from 2012 to 2020, it is because this period attracted the attention of the researchers as it is when the country had different parties engaging in coalitions to form the government. Within seven years, Lesotho has had four coalition governments that all could not finish their term of five years. In undertaking the study, the researchers aimed at ascertaining the economic cost of political conflict during coalition governments in Lesotho from 2012 to 2020 and find out the manifestations of this cost. The research further intended to come up with suggestions for remedial actions to the government of Lesotho to bring about stability in future coalition governments.

This study used both the qualitative and quantitative approaches. Studying diverse economic costs of conflict within coalition governments and the extent to which conflict impacted the socio-economic development of the country warranted a qualitative approach. The researchers also conducted personal and telephonic interviews with the political leaders, political activists, civil society organisations, National Assembly speakers, clerks, government officials and security agencies to collect primary data.

The costs of conflicts within the coalition governments also attracted a quantitative presentation and explanation. The study adopted some economic indicators to measure the performance of coalition governments from 2012 to 2020, including the capital budget, among others. It was deemed necessary to reflect on certain variations in the data in the period given. However, it was necessary for some economic indicators to expose a full picture of their behavioural pattern over this time period through graphs, variations and trends that could only be understood when shown a few years earlier than 2012 and after 2020 using projected data. Most of this data was derived from various documents. Therefore, secondary data was to support and strengthen the primary data. The documents that were used included reports, papers, receipts, digital or analogue media such as audio tapes or CDs.

All collected data were grouped into themes created from the research objectives and subthemes were derived from the research questions. The interpretive analysis was adopted to give full meaning to the data to unfold the existing scenario on the economic cost of political conflict on Lesotho's development. 


\subsection{Lesotho coalition governments and political conflict}

One of the most difficult issues to control and which has an unbearable impact on social and economic development in developing countries has been political instability. Political instability is explained as a situation or process whereby society is drenched in obvious and concealed conflicts, which in turn result in serious threats to its social being (Matlosa, 1997). Matlosa argues that Lesotho, a developing country, is not excluded from the general tendency of instability which is generated by various conflicts, prominent among them being political conflicts.

Lesotho's 2012 general elections were historic. The country moved from a single-party government under the Lesotho Congress for Democracy (LCD) led by the former Prime Minister, Pakalitha Mosisili, in 1997, to a coalition government of three political parties. In 2011, the intra-political conflict within the LCD produced strong political factions known as "Fire Extinguishers" (Litima-Mollo) and "Fire Absorbers" (Lija-Mollo). The unresolved political power struggle within the LCD resulted in a split that gave birth to the Democratic Congress (DC). The resulting circumstances forced the then Prime Minister Mosisili to dissolve parliament and call for fresh elections. On the eve of the announcement of the poll results by the Lesotho Independent Electoral Commission (IEC) on Tuesday 29 May 2012, it was clear that no party had amassed the requisite 61 out of 120 seats in the National Assembly to form a government. This resulted in confusion and controversy (Motsamai, 2012). The DC, being the leading party with 41 seats, failed to win the outright majority but was threatening to form a minority government.

From Lesotho's independence in 1966 to 2012, successive governments were formed by single political parties because they each managed to garner a sufficient majority to form the government. Given the situation, there was no controversy, hence no need to negotiate the formation of government. The situation came to a halt following the 2012 general elections when Lesotho experienced the first coalition government. Circumstances forced political parties to negotiate the formation of a coalition government. The leaders of the All Basotho Convention (ABC), LCD and Basotho National Party (BNP) held a press conference to announce their intention to form a coalition government. They subsequently wrote a letter to the King, the Head of State, informing him about their intention. The first coalition government did not complete its five-year term. It collapsed within two years, plunging the kingdom into a new era of political uncertainty. There was an inter-partyl conflict between ABC and LCD. The then Deputy Prime Minister, Mothejoa Metsing, was accusing the Prime Minister, Thomas Thabane, of making unilateral decisions to the exclusion of other coalition partners. The conflict was exacerbated by the prorogation (suspension) of parliament for nine months and ultimately a snap election in 2015. 
The situation of a hung parliament recurred in the aftermath of the 2015 snap elections. The elections gave birth to yet another hung parliament where no single political party had won the majority of the seats in the National Assembly. The 2012 general elections results had set a precedent, so the 2015 elections, failing to produce an outright winner, necessitated negotiations that led to the formation of the second coalition government, which was composed of seven political parties led by the former Prime Minister, Mosisili. Within a short space of time, the Mosisili-led coalition of political parties was unstable. The instability emanated from within the DC, which was the senior partner in the coalition of the seven political parties which displayed intra-party conflict.

The DC infighting had heightened to the birth of two factions, "Butterflies" (Lirurubele) and "Girls" (Lithope), with the former said to be pro Mosisili while the latter was said to be sponsored by his Deputy, Monyane Moleleki. As tensions mounted, a motion of noconfidence was filed against Mosisili's government. Having lost the vote of a no-confidence motion in parliament, Mosisili dissolved parliament in 2017 and called for snap elections. Consequently, for the second time, Lesotho's government could not complete its first fiveyear term ('Nyane, 2016).

Following the 2017 snap elections, the ABC, having won 51 out of the 120 parliamentary seats, was not an outright winner. As a result, the party negotiated with the Alliance of Democrats (AD), the Basotho National Party (BNP) and the Reformed Congress of Lesotho (RCL) to form the third coalition government.

The total cost of the three snap elections in Lesotho in the space of five and half years is estimated to be M900 000000.00 (Nine Hundred Million Maloti) (Public Accounts Committee Report, 2019). Given this background, this raises a concern about the coalition governments failing to complete the five-year term, mainly due to conflicts that have proved far too costly. The chapter examines the economic cost of conflict as a result of inter and intra-political disagreements between coalition partners in Lesotho from 2012 to 2020. The chapter looks at the conflict in Lesotho from the insights provided by other scholarly works which similarly explained conflict and how such conflict could display itself as provided in the following section. These are the definitions on which this study was anchored in explaining what caused conflict during Lesotho coalition governments.

\section{Conceptual framework}

\subsection{Conflict}

Scholars have come up with several definitions of conflict. Conflict is an existing state of disagreement or hostility between two or more people. This occurs when two or more parties do not have an agreement and areas such as two different parallels on the same issue. 
It, therefore, suggests the pursuit of goals that are not compatible. Conflict means a collision course; it also refers to opposition to an existing view, stands or position (Nicholson, 1992).

Morgenthau (1948) (as cited by Pham, 2009) asserts that conflict is the most noticeable feature of human society. He further argues that men fight even if they do not have arms or when the tools of violence are not accessible. When there are no arms to fight with, men fight even with their bare fists. From birth, a baby begins the journey of conflict by crying, which is a flash of conflict, according to Morgenthau (1948). As the child grows up, he/ she bites with the teeth and scratches with the nails on the little fingers when upset. These actions presuppose that people will continue to fight as long as they have emotions that have the potential to love or hate, to be happy or sad, to be pleased or angry. As long as man has other men around him, there will be issues of disagreement because interests differ and interests do clash subsequently, leading to disagreement or confrontation.

Nicholson (1992) further defines conflict as an existing state of lack of consensus or unfriendliness between two or more people. According to Follett (2011), conflict is the appearance of differences, the difference of opinion, and interest. He argues that in a conflict, there is a strong tendency to attribute the blame to other people. Austin (1976) (as mentioned in Bornstein, 2003) also defines conflict as a disagreement between two or more individuals or groups. Each individual or group tries to gain acceptance of its view or interests over others.

Viewed from an extreme and religious perspective, conflict represents one of the two natures of man. One nature is "evil". Its opposite embodies the second, which is the "good" nature of man. St. Augustine (2050) maintains that conflict manifests in disagreement, anger, quarrel, hatred, destruction, killing, or war. Any untoward attitude capable of charging up the political or social environment is likely to culminate in conflict. Greed, covetousness, self-centeredness, discontent, envy, arrogance, rudeness, impunity, among other acts, are capable of producing a breakdown in human relations. In a way, these vices are innate attributes of the "conflict nature" of man.

Louis (2017) defines conflict as an antecedent condition. For instance, scarcity of resources and policy differences among individuals lead to conditions of conflict. It is a process that begins when one party perceives that another party has negatively impacted something that the first party cares about. Conflict is also a psychological state of mind when people are in a dilemma concerning whether to do or not to do something.

From this explanation, we can conveniently define conflict as a disagreement characterised by antagonism and hostility among groups or individuals. In the political sphere, this is usually fuelled by one party's opposition to the policy of another in an attempt to reach an objective different from that of the other party. Researchers have called these "political conflicts". 


\section{The economic impact}

The period under which Lesotho had coalition governments exposed the most critical constraints that stalled the country from achieving its long-term economic development objectives of inclusive and sustainable growth, employment creation and poverty reduction. Economic development is a broad concept, encompassing the country's social and economic progress. The extent to which a country has achieved economic development considers a range of economic indicators, mainly capital budget, as a share of GDP. The capital budget is particularly important because it is the portion of the government budget that comprises funds that are mainly appropriated for programmes and investment projects that are expected to yield a positive return to the economy. According to Ogujiuba and Ehigiamusoe (2014), capital projects include the construction of roads, bridges, hospitals, schools, prisons, public administrative buildings, highways, dams and irrigation systems, acquisition of machinery and equipment, the supply of water and electricity, availability of transport, health and educational facilities. Therefore, if the capital budget is well-executed, it is likely to boost the general economy of a country. While other indicators such as investment appraisal and prioritisation, government revenues, capital absorptive capacity and budget support also contribute significantly to the performance of the economy.

\subsection{Capital budget as a share of GDP}

From 2012 to 2020, the proportion of capital budget allocation has always been below that of the recurrent budget as a result of conflict among coalition partners. The Public Expenditure and Financial Accountability (PEFA) assessment conducted in 2012 further confirms that the execution of capital projects in Lesotho deviates considerably from the budget outlines. Further, in 2017 the PEFA indicated that the expenditure budget was a major concern for service delivery, as the original intentions of the budget as approved by parliament to meet service delivery were derailed by in-year decisions to the reallocation of budget. Table 16.1 depicts the split between the capital and recurrent expenditure budget for the Fiscal year 2011/12 to 2019/20.

Except for a few years, the proportion of the capital budget allocation has been below that of the recurrent. The government planned to eventually have them at par as per the 2010/11 budget speech. This was somehow achieved in the 2011/2012 fiscal year at a speed of 53 to $47 \%$ in favour of the capital budget. However, over the years and particularly in the 2019/20 budget allocation, 73\% of the budget had been allocated to recurrent expenditure, leaving only $27 \%$ for the development component. This shows a huge imbalance in the development prioritisation of the country. 
Amongst the major contributing factors to the ballooning recurrent budget is the emergence of the coalition governments since 2012 that kept on expanding the Cabinet significantly. In the 2013/2014 budget speech, the Minister of Finance, Leketekete Ketso admits that annual budgets are just a constitutional formality without any meaningful transformation to the lives of Basotho. He stated that the huge allocation of the annual budget towards the recurrent expenditure compromises resources required for service delivery, public investment and the incentive for the private sector engagement. It, therefore, leaves too little room for development.

Based on the findings of the study conducted by Olatunji, et al. (2017) in Nigeria, capital expenditure implementation is appropriate to maintain and sustain economic growth as it can influence the growth of the economy in the long run for some sectors. However, the declining capital budget in the case of Lesotho does not augur well for economic growth and could explain the picture depicted of declining GDP growth (Table 16.1). Figure 1 also illustrates declining capital expenditure over a time period after 2012, a further negative impact on the development of the country.

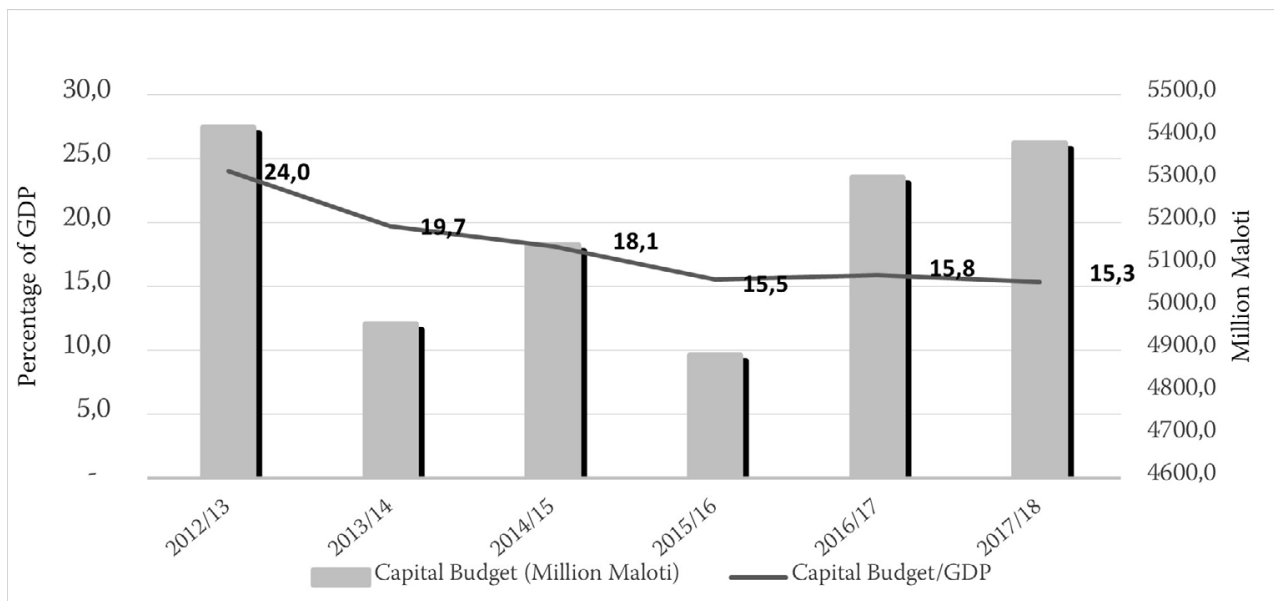

Figure 16.1 Capital budget, 2012/13-2017/18 (Million Maloti and as a share of GDP)

Source: Ministry of Finance (2019)

The table above shows a decline of the capital budget as a share of GDP from as high as $24 \%$ in $2013 / 14$ to $15.3 \%$ in $2017 / 18$ and it further declined to $14.76 \%$ by $2019 / 20$. It should be noted that recurrent expenditure has been growing (Table 16.1). Table 16.1 shows the proportion of the Capital Budget to Recurrent Budget for the period 2012/13 to 2019/20. 
Table 16.1 Proportion of capital budget to recurrent budget

\begin{tabular}{|c|c|c|c|c|c|}
\hline $\begin{array}{c}\text { Financial } \\
\text { year }\end{array}$ & $\begin{array}{c}\text { Total capital } \\
\text { budget } \\
\text { allocation }\end{array}$ & $\begin{array}{l}\text { Total } \\
\text { recurrent } \\
\text { budget } \\
\text { allocation }\end{array}$ & Total budget & $\begin{array}{l}\text { Capital/ } \\
\text { total } \\
\text { budget } \\
(\%)\end{array}$ & $\begin{array}{c}\text { Recurrent/ } \\
\text { total budget } \\
(\%)\end{array}$ \\
\hline $2011 / 12$ & 5134411105 & 4613266118 & 9747677223 & 53 & 47 \\
\hline $2012 / 13$ & 5369743527 & 11310894848 & 16680638375 & 32 & 68 \\
\hline 2013/14 & 4828264951 & 4126205225 & 8954470176 & 54 & 46 \\
\hline 2014/15 & 5027655788 & 10821072856 & 15848728644 & 32 & 68 \\
\hline 2015/16 & 4133677015 & 14440245575 & 18573922590 & 22 & 78 \\
\hline 2016/17 & 5865687917 & 11744564000 & 17610251917 & 33 & 67 \\
\hline 2018/18 & 5716112819 & 12463533000 & 18179645819 & 31 & 69 \\
\hline 2018/19 & 5545776549 & 14778493000 & 20324269549 & 27 & 73 \\
\hline $2019 / 20$ & 5168475415 & 13843576000 & 19012051415 & 27 & 73 \\
\hline
\end{tabular}

Source: Ministry of Finance (2019)

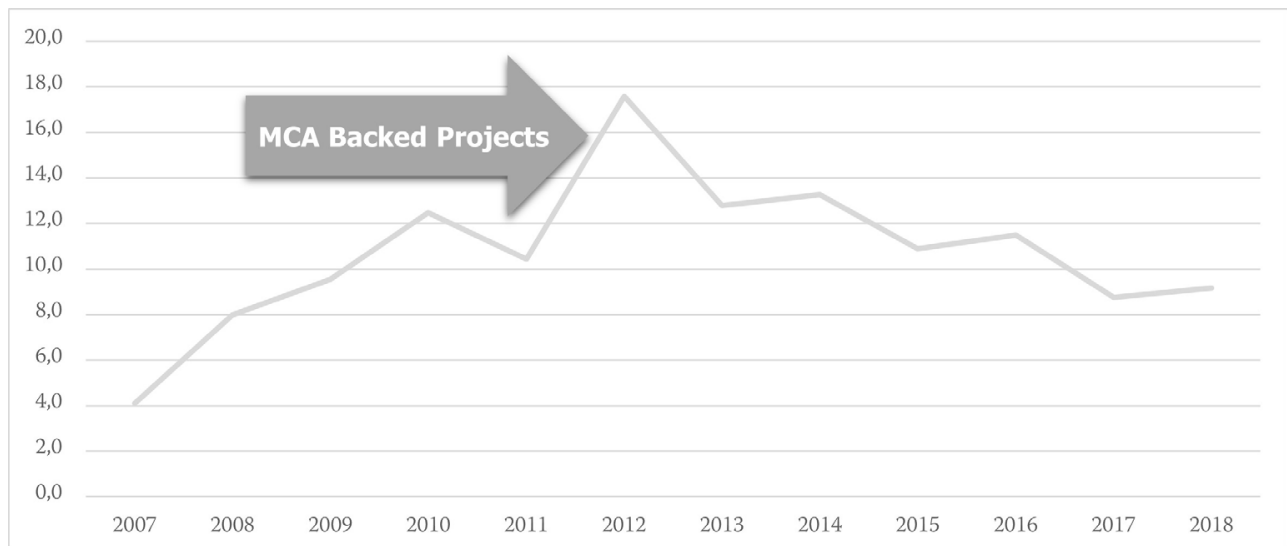

Figure16.2 Increase in capital expenditure

Figure 16.2 illustrates that the capital expenditure registered an average increase of $34.8 \%$ between 2007/08 through 2010/11. Between 2008/09 and 2009/10 there was an increase of 53.2 and $52.1 \%$ respectively, resulting from the additional capital injection from the Government of Lesotho as well as the increased counterpart funding of projects. There was a slight decline in 2010/11 due to the adoption of the expenditure reduction policy and the significant decline in foreign loans. As a result, nonfinancial assets grew by an average of 50.5\%. This included, among others, the up-grading of the Likalaneng to ThabaTseka road, construction of secondary schools, and construction of a new referral hospital (QMMH) funded by MCA. The capital expenditure registered 39.2\% in 2011/12, before increasing by $27.8 \%$ in $2012 / 13$. This growth was attributed to the construction of the 
Metolong dam, which was at full scale in 2013/14 and 2014/15. An average decline of $18.6 \%$ was observed in the following years as the MCA projects and other donor-funded projects were phasing out.

\subsection{Declining government revenues 2012/13-2017/18}

Since 2012, coalition governments were not able to increase tax revenues as this component stayed constant at around 20\% (Figure 16.3). In the 2017/18 budget speech, the then Minister of Finance, Moeketsi Majoro, pointed out that over the years, the government of Lesotho was unable to generate adequate domestic revenue for the economy. Among others, he attributed this to the mounting political instability that dampened the prospects for the growth of the economy and that there is no significant involvement of the private sector for productive activities that create sustainable jobs and the required tax revenue.

Figure 16.3 depicts the trend of revenue from 2013 to 2018 as a share of GDP. With the onset of the global financial crisis, SACU revenues declined from 13.3\% of GDP in the financial year 2010/11 and financial year 2011/12, respectively, thereby leading to a call for a sharp fiscal consolidation. Because of the drop in SACU revenues, the Government had to cut the recurrent spending by $10 \%$ of the GDP in the financial year 2010/11. The Country embarked on a fiscal consolidation programme, supported by the International Monetary Fund (IMF) Extended Credit Facility (ECF), in response to the rising fiscal pressures. It managed to cut expenditures by $11 \%$ of GDP in 2010. However, capital spending was mostly preserved. As soon as SACU revenues rose again in the financial year 2012/13, during the first coalition government, expenditures also started to rise. As already stated the ballooned cabinet expenditure became high.

Despite this, SACU revenues declined from 25\% in the financial year 2014/15 to $13.6 \%$ of GDP in FY 2016/17, mostly due to the slower growth in South Africa. The overall revenue declined from $56 \%$ of GDP at the beginning of the NSDP 1 to $43 \%$ of GDP at the end of the plan. This reflects declining SACU receipts while tax revenue had been constant at around 21\% of GDP. Grants declined from 4\% to 2\% of GDP while other nontax revenues increased by 1\% between FY 2012/13 and FY 2016/17 before declining back to $4 \%$ of GDP in $2017 / 18$. The decline in SACU revenue narrowed the fiscal space and has led to a considerable decline in fiscal buffers. The country missed an opportunity to make a gradual adjustment in FY 2016/17. Lesotho's fiscal deficit reached 8\% of GDP in FY 2016/17. Due to limited borrowing opportunities, the Government financed the deficit through a drawdown of government deposits at the Central Bank resulting in a decline of the reserves. The reserve coverage declined from 6.1 months of imports in FY 2015/16 to 4.2 months of imports at the end of FY 2016/17 (World Bank, 2017). This indicates clearly that the country generates lesser revenue for its fiscal spending, resulting in a depletion of national reserves to finance the spending. The declining revenue implies that fiscal space for further capital expansion is limited. 


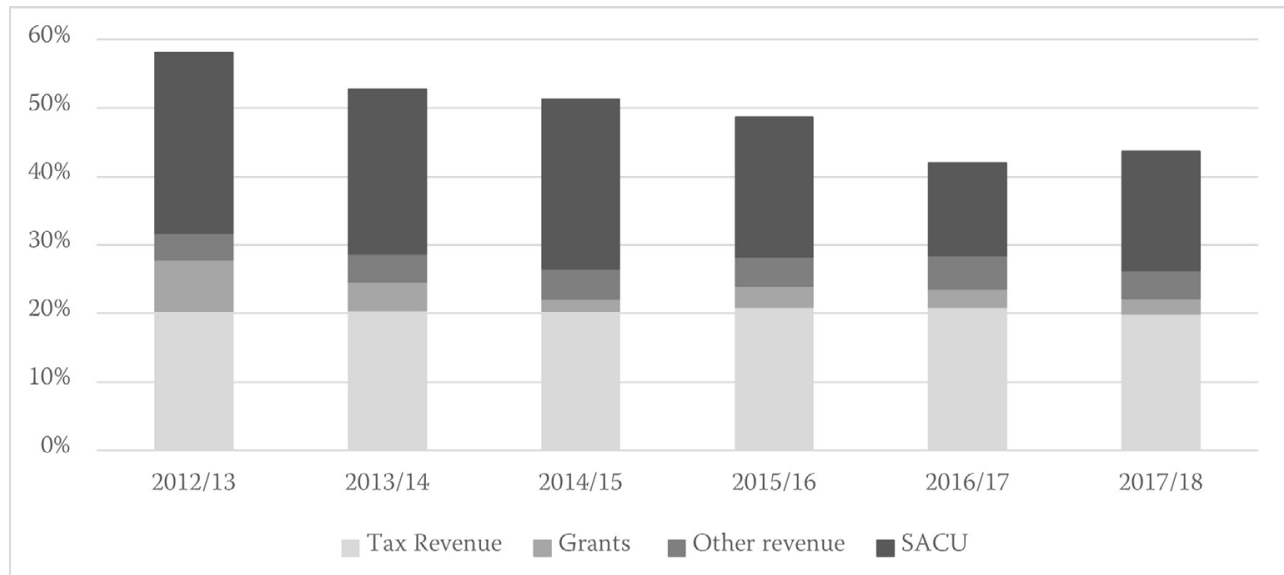

Figure 16.3 Sources of government revenue, 2012/13-2017/18 (share of GDP)

\subsection{Lack of project investment appraisal and prioritisation}

Due to the conflicts within the coalition governments, there were occasions where certain projects were implemented without being subjected to PSIC. As a means to address the projects' implementation failure, the cabinet established the Public Sector Investment Committee (PSIC) in September 2013 as a body that appraises project concepts and proposals to ascertain their financial and economic viability and sustainability as well as their technical, institutional, environmental and social aspects, in accordance with the set project appraisal guidelines. The projects that meet the requirements form part of the Public Sector Investment Programme (PSIP) and are recommended for funding.

The intention of the PSIC is to institute a uniform and transparent process of project formulation and appraisal. In government, all projects must be approved by the PSIC before they are recommended to the Cabinet budget sub-committees as pipeline prospective projects for inclusion in the PSIP. This principle also applies to the projects that are funded, wholly or in part, by Lesotho's external development partners to ensure that the assistance rendered by the donors and loan providers addresses the national priorities. Nonetheless, project failure was quite remarkable from 2012 to 2020.

For example, the construction of the Principal chiefs' offices in the Ministry of local government and chieftainship was started in most of the wards in 2012. However, for some of the offices such as Maama, Matsieng and Maqhaka construction started in the past seven years has not been completed till now. Each of them was supposed to be built at the cost of a maximum of M3 million (Ministry of Finance, 2019). This project became too costly for the government. 
In addition, the Palace construction project, which started in the 2011/12 financial year during the first coalition government in Lesotho, did not go through proper appraisal processes. Later, the construction works audit was done. Its report revealed many technical and construction defects that necessitated a revisit to the project, thus adding to its costs and life cycle. Garmann (2014) argues that it is difficult for coalition government partners to agree on certain policy areas when there is conflict among them. As a result, coalitions are likely not to approve some projects in cases where there is no consensus. In these cases, there is the potential for projects to be undertaken without appraisals or not to be undertaken at all and thus be costly in the long run.

Evidence shows that the costs are contained where the guidelines to project implementation have been properly followed, as is the case with the Mokhotlong road construction that started in 2012 in the first coalition. This project was completed on time with small variations that were known and approved. The variations included an additional cost of around M16 million for a footbridge and paving around and beyond the Sani border gate, costing around M11 million. Because of proper planning throughout the appraisal process of this project, its implementation was a success, and it was executed within the planned period.

The following projects (Tables 16.2 and 16.3) are examples of the success and failure scenarios as a result of the set assessment requirements.

Table 16.2 Construction of the Royal Palace

\begin{tabular}{|c|c|}
\hline Project name & Construction of the Royal Palace \\
\hline Appraisal Date & Not appraised \\
\hline Initial Estimated Cost & M136 000 000.00 \\
\hline Start Date & 2011/12 (August 2011) \\
\hline Initial End date & 2013/14 (August 2013) \\
\hline Additional financing Appraisal Date & August 2017 \\
\hline Revised Cost & M474 676747.89 \\
\hline $\begin{array}{l}\text { Expenditure to date (as at end of Dec } \\
\text { 2019) }\end{array}$ & M401 127664.01 \\
\hline Revised End Date & 2018/19 (September 2018) \\
\hline Re-Revised Cost & M540 127664.00 \\
\hline Re-revised End Date & 2020/21 (August 2020) \\
\hline
\end{tabular}

Source: Ministry of Finance (2019) 
Table 16.3 Construction of a 44km road from Mokhotlong to Sani Pass

\begin{tabular}{|l|l|}
\hline Project Name & Construction of Mokhotlong - Sani Pass Road \\
\hline Appraisal Date & $2010 / 11$ \\
\hline Initial Estimated Cost & M740 000 000 \\
\hline Start Date & May 2012 \\
\hline End date & Dec 2015 \\
\hline Actual Expenditure & M767 000000 \\
\hline
\end{tabular}

Source: Ministry of Finance (2019)

\subsection{Low capital absorptive capacity}

Not only does the capital budget as a share of GDP decline but there is also evidence of delay in the execution of projects and an under-spending of the capital budget during the period of coalition governments. This delay is depicted in Table 16.4 that shows a weak absorptive capacity in the implementation of the capital budget. According to the Cabinet sub-committee on a budget (2015/16), reallocation of the capital budget was made and unused funds were allocated to the ministries with a high absorptive capacity. For instance, in 2015/16 the capital budget was reallocated to those ministries that fully utilised their initial capital budget, hence the $77 \%$ of implementation of the development budget that year. Minister Khaketla's (2015) budget speech indicated that the Ministry of Energy was the only ministry that managed to utilise the capital budget within two quarters and was reallocated more funds in the financial year 2014/15.

Some reasons explain the weak absorptive capacity of the capital budget. The frequent changes to the political and administrative leadership of the ministries have delayed the policy making and the execution of policy in Lesotho. For instance, in the key ministries such as Finance, Health, Education and Public Works there have been major reshuffles, with the ministry of Finance standing at a high of four reshuffles since 2012. UNICEF (2017) points out that cabinet reshuffles are highly disruptive to the work of government, as new ministers normally take time to settle in and familiarise themselves with the policy, legislation and programmes of a particular ministry. This, in return, results in the bureaucratic and irregular cycle of policy-making and eventually affects the economy negatively.

In addition, the lack of checks and balances and the increasing levels of corruption in the public sector is exacerbated by the political executive interfering in the procurement process. The irregularities in this process also delay capital spending, resulting in continuous underspending of the capital budget. For instance, in the 2017 budget speech, the then Minister of Finance, Moeketsi Majoro, reminded the newly appointed ministers not to be tempted to involve themselves directly in the procurement process as their role is the 
political direction and general supervision of the ministries. He pointed out that the Bidvest Bank fleet decision was one clear example of how far things can go wrong when the cabinet is directly involved in procurement decisions. This was the biggest scandal of awarding the government tender to a foreign firm that ended up draining the government coffers by almost M1 billion. Another example where ministers got involved in the procurement process, and thus caused delays in capital budget execution, was in the awarding of a tender for Mpilo Boulevard, which was meant to reduce traffic congestion in the city and to reduce car accidents. In this case, Ministers Chalane Phori and Mahala Molapo ordered that the award of M380 million tender be given to their preferred bidder.

Table 16.4 Trends in capital absorptive capacity

\begin{tabular}{|lc|c|c|}
\hline Financial Year & Approved & Expenditures & $\%$ \\
$2011-2012$ & 5134411105 & 2829517996 & 55 \\
$2012-2013$ & 5369743527 & 1909142770 & 36 \\
$2013-2014$ & 4828264951 & 2215028705 & 46 \\
$2014-2015$ & 5027655788 & 3252443956 & 65 \\
$2015-2016$ & 4133677015 & 3179230661 & 77 \\
$2016-2017$ & 5865687917 & 1440961345 & 25 \\
$2017-2018$ & 5716112819 & 2866653450 & 50 \\
$2018-2019$ & 5545776549 & 3349788110 & 60 \\
\hline
\end{tabular}

Source: Ministry of Finance (2019)

\subsection{Loss of budget support}

Given that Lesotho had episodes of difficult political transition periods before 2012, there was little scope for stepping up government investment to support inclusive growth at the time. This is mainly because the government size had almost doubled, following the 2012 coalition government which led to a further expansion of recurrent expenditure, especially in the wage bill, coupled with the weakening of the revenue collections.

Subsequent to the political events of 2012 and the following years, the Lesotho government suffered a loss of budget support that it had been receiving from its development partners. The capital grants from the development partners dwindled, as Figure 16.4 illustrates. As the trend shows, after the formation of the first coalition government in 2012 and the political events that followed thereafter, the Lesotho Government suffered the loss of budget support that it had been receiving from its development partners. This had a negative impact on the capital budget as some of its components were affected. For instance, capital grants from development partners had been declining. Project grants in 2019/20 stood at M1 262 million, the highest since the fall of capital grants in 2013/14 and well above the 6-year average of M984 million between 2013/14 and 2017/18 before falling to M1 108.4 million 
(2.9\% of GDP) in 2020/21. Grants are expected to average M1 164.8 million (2.8\% of GDP) between 2021/2 and 2022/23. The government lost another EU budget support in 2015/16. This further contributed to the declining capital budget. Figure 16.4 depicts the current and projected trend in budget support.

UNICEF (2017) disclosed that some interviewed officials noted that the inability of the Lesotho government ministries to meet their agreed targets had driven development partners away from their budget support. The implications of declining revenue sources may push the government to borrow more and thus increase debt ratios above the indicative thresholds.

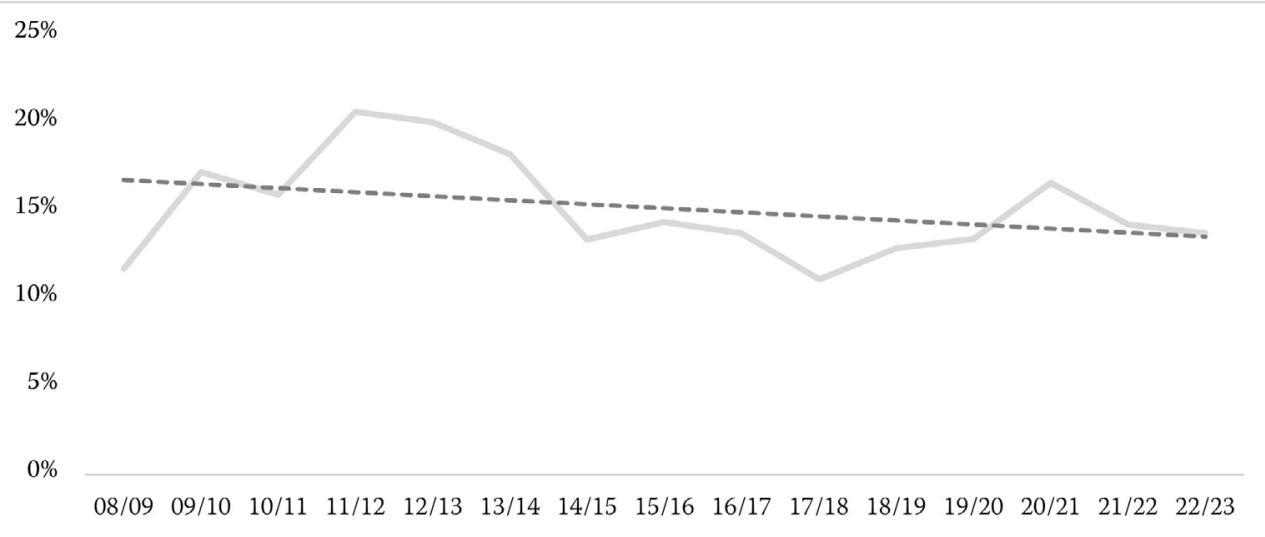

\section{Figure 16.4 Loss of actual and estimated budget support}

\section{Conclusion and recommendations}

Conflict has been the feature of the Lesotho political landscape since independence. However, coalition politics worsened it because of intra-party and inter-party clashes. Several factors contributed to the conflict. The fight over power-sharing was imminent between the coalition partners with setbacks on the economy. The ensuing effects of this political conflict were more remarkable from 2012 to 2020 in the reign of the coalition governments negatively affecting economic development in many ways. The decline of the capital budget as a share of GDP from as high as 24\% in 2013/14 to $15.3 \%$ in 2017/18 and a further decline to $14.76 \%$ by $2019 / 20$, with the recurrent expenditure growing (Table 16.2), indicates that less attention is given to development because it is from the capital budget that the country finances the infrastructure development needed for economic growth accumulation. The proportion of the capital budget allocation has always been below that of the recurrent budget though the plan was to eventually have them at par. In the 2019/20 budget allocation, $73 \%$ of the budget went into recurrent expenditure while $27 \%$ remained for capital development, compromising the welfare of the masses of the poor, while, SACU 
revenues have been declining steadily from 2009/10 from 30\% of GDP due to the slow growth in South Africa to $4 \%$ of the GDP in 2017/18. This means that the country was further becoming constrained to meet fiscal spending, as most of the expenditure is met from the collected revenue, further creating a bottleneck towards development.

In addition, there were projects that were not properly appraised but were allocated funds. These were the projects that attracted additional funding because they were not properly appraised. Examples are the construction of the Royal Palace and the Construction of a $44 \mathrm{~km}$ road from Mokhotlong to Sani Pass. The loss of money with the development projects which have to be backed up to reach completion create serious budget constraints and stresses the already sluggish economy because other development priorities have to be postponed. Whereas, in 2016/17, Lesotho experienced the lowest capital budget absorptive capacity, attaining only $25 \%$ of the funds' utilisation. As conflict continuously manifests itself in Lesotho's coalition politics, the coalition partners focus on how to deal with conflict among themselves, losing the focus on undertaking economic development activities. This means a lesser utilisation of allocated funding to reach out to the nation through services delivery.

Due to constant political instability in Lesotho, the country lost budget support from the European Union to the tune of M473 460 000. With an already fragile economy from the political unrest, losing extra opportunities to support the economy means taking a step backwards in achieving development because some of these funds are earmarked for services delivery at the grassroots level. Furthermore, the country has missed some economic opportunities as investors constantly ran away for fear of losing their lives and property during the conflict in the three consecutive coalition governments.

In order to ameliorate the deteriorating socio-economic conditions which are severely affected by perpetual political conflict among the partners in the coalition government, some remedial measures that can be undertaken to take Lesotho to a socially, economically and politically sustainable path are as follows:

In order to increase the declining capital budget share of GDP used in financing capital development necessary for the country's growth, the government needs to allocate more capital funding. This will enhance its capacity to invest in capital development projects that will generate more growth in the economy to meet the nation's basic services demands.

The Government should financially boost and support the private sector so that individual citizens may start their businesses. This will further increase the GDP from which the country can meet its development activities. Furthermore, this will help to create more jobs for the growing labour force. This will also reduce the competition for parliamentary seats and ministerial positions, which are the sources of political instability in Lesotho. 


\section{REFERENCES}

Austin, D. L. (1976). Conflict: A more professional approach. Personnel Administrator, 21(5):28-32. https://doi.org/10.1108/eb055306

Bornstein, G. (2003). Intergroup conflict: Individual, group, and collective interests. https://doi.org/10.1207/S15327957PRO702_129-145.

Follett, M.P. (2011). Constructive conflict. In: H.C. Metcalf \& L. Urwick (eds.), Dynamic administration: The collected papers of Mary Parker Follett. (pp. 30-49)

Garmann, S. (2014). The causal effect of coalition governments on fiscal policies: Evidence from a regression kink design. Applied Economics, 46(36):4490-4507. https://doi.org/10 $.1080 / 00036846.2014 .964831$

Government of Lesotho. (2019). Public accounts. Maseru: Parliament.

Louis, K. (2015). Realizing peace: A constructive conflict approach. New York: Oxford University Press.

Matlosa, K. (1997). The 1993 elections in Lesotho and the nature of the BCP victory. African Journal of Political Science/Revue Africaine de Science Politique, 2(1):140-151.

Ministry of Development Planning. (2018). National Strategic Development Plan I. Maseru: Government Printing Unit.

Ministry of Finance. (2010). Budget speech 2010/2011. Maseru: Ministry of Finance.

Ministry of Finance. (2012). Budget speech 2012/2013. Maseru: Ministry of Finance.

Ministry of Finance. (2013). Budget speech 2013/2014. Maseru: Ministry of Finance.

Ministry of Finance. (2014). Budget speech 2014/2015. Maseru: Ministry of Finance.

Ministry of Finance. (2017). Budget speech 2017/2018. Maseru: Ministry of Finance.

Ministry of Finance. (2018). Budget estimates. Maseru: Government Printing Unit.

Ministry of Finance. (2019). Budget estimates. Maseru: Government Printing Unit.

Morgenthau, H.J. (1948). Politics among nations. New York: Alfred A. Knoof.

Motsamai, D. (2012). Lesotho: after May 2012 general elections making the coalition work. 12 June. https://bit.ly/3GFINos [Accessed 2 March 2020].

Nicholson, M. (1992). Rationality and the analysis of international conflict. London: Cambridge University Press. https://doi.org/10.1017/CBO9780511598739

'Nyane, H. (2016). Formation of a government in Lesotho in the case of a hung parliament. Law, Democracy and Development, 20:174-191. https://doi.org/10.4314/Idd.v20i1.9

'Nyane, H. (2017). The advent of coalition politics and the crisis of constitutionalism in Lesotho. In M. Thabane (ed.), Towards an anatomy of persistent political instability in Lesotho, 1966-2016. Lesotho: Morija Printing Works.

Ogujiuba, K. \& Ehigiamusoe, K. (2014). Capital budget implementation in Nigeria: Evidence from the 2012 capital budget. Contemporary Economics, 8(3):299-314.

Olatunji, O.C., Oladipupo, O.F. \& Joshua, A.A. (2017). Impact of capital budget implementation on economic growth in Nigeria. Archives of Business Research, 5(10):89-102.

Pham, P. (2009). Hans J. Morgenthau and United States policy toward Africa, American foreign policy interests. Journal of National Committee on American Foreign Policy, 31(4):252-260.

St Augustine (1950). The city of God. London: Penguin Books.

UNICEF (2017). Political economy analyses of countries in Eastern and Southern Africa: case study: Lesotho political economy analysis. https://uni.cf/3oRPOMR [Accessed 10 February 2020].

World Bank Group. (2017). Lesotho: Systematic country diagnostic, 25 June. 